\title{
Problematika Validasi Pajak Oleh Kantor Pajak Pratama Terhadap Akta PPAT
}

\author{
Mohammad Taufan Kumangki \\ Magister KenotariatanFakultas HukumUniversitas Islam Indonesia \\ Jln. Cik Di Tiro No. 1, Yogyakarta, 55223 \\ samkumangki@gmail.com
}

\begin{abstract}
This study aims to examine the problems of tax validation by the Pratama Tax Office on the Deeds of Land Titles Registrar (PPAT). This research uses normative legal study on the principles, norms, rules of statutory regulations, court decisions, agreements and doctrines. The results of this research conclude that the legal consequence of the pending tax validation process on the PPAT Deed Registration is that tax validation is a state administrative task, the absence of validation of the sale and purchase tax results in the inability of sale and purchase registration for the transfer of rights to land to the Land Office. By customary law, the sale and purchase paid in full results in the buyer having obtained the right to the land, but because the sale and purchase certificate has not been registered to the Land Office, the land has not been legally transferred to the Buyer. Furthermore, in order to solve these problems by referring to the problems encountered in practice, the BPHTB tax validation process with the income tax validation at the Pratama Tax Office shows that there is a lack of files submitted or underpayments of previously paid taxes, hence taxpayers personally or through their proxies are requested to amend or complete the missing documents, to be able to re-apply for validation, this takes a long time and PPAT in Manado City has to make a statement of delay on the Sale and Purchase Deed.
\end{abstract}

Key Words: PPAT, tax, transfer of land rights

\begin{abstract}
Abstrak
Penelitian ini bertujuan untuk mengkaji problematika validasi pajak oleh Kantor Pajak Pratama terhadap Akta Pejabat Pembuat Akta Tanah (PPAT).Penelitian inimenggunakan penelitian hukum normatif terhadap asas-asas, norma, kaidah dari peraturan perundang-undangan, putusan pengadilan, perjanjian serta doktrin. Hasil dari penelitian ini menyimpulkan bahwa akibat hukum proses validasi pajak yang tertunda terhadap Pendaftaran Akta PPAT adalah, bahwa validasi pajak merupakan tugas administrasi negara, tidak adanya validasi terhadap pajak jual beli mengakibatkan tidak dapat dilakukannya pendaftaran jual beli untuk peralihan hak atas tanah ke Kantor Pertanahan. Secara hukum adat, jual beli yang dibayar secara lunas mengakibatkan pembeli telah memperoleh hak atas tanah tersebut, namun karena belum dilakukan pendaftaran akta jual beli ke Kantor Pertanahan, maka tanah tersebut secara yuridis belum beralih ke Pembeli. Selanjutnya, untuk penyelesaian problematika tersebut dengan mengacu pada problematika yang ditemui dalam praktik, proses validasi pajak BPHTB dengan validasi pajak penghasilan di Kantor Pajak Pratama terdapat kekurangan berkas yang diajukan atau kurang bayar terhadap pajak yang telah dibayarkan sebelumnya, wajib pajak secara pribadi maupun melalui kuasanya diminta untuk melakukan perbaikan atau melengkapi berkas yang kurang, untuk dapat diajukan validasi kembali, hal ini membutuhkan waktu yang lama dan PPAT di Kota Manado harus membuat pernyataan keterlambatan atas Akta Jual Beli tersebut.
\end{abstract}

Kata-kata Kunci: Pajak, peralihan hak atas tanah, PPAT 


\section{Pendahuluan}

Ketentuan Pasal 1 angka 24 Peraturan Pemerintah Nomor 24 Tahun 1997 tentang Pendaftaran Tanah menyebutkan "Pejabat Pembuat Akta Tanah, selanjutnya disebut PPAT adalah Pejabat Umum yang diberi kewenangan untuk membuat akta-akta tanah tertentu". Pengertian lain mengenai PPAT juga terdapat di dalam ketentuan Peraturan Pemerintah Nomor 24 Tahun 2016 tentang Perubahan atas Peraturan Pemerintah Nomor 37 Tahun 1998 tentang Peraturan Jabatan Pejabat Pembuat Akta Tanah (PP No. 24 Tahun 2016). Pasal 1 angka 1 PP No. 24 Tahun 2016 menyebutkan bahwa "Pejabat Pembuat Akta Tanah, selanjutnya disebut PPAT, adalah pejabat umum yang diberi kewenangan untuk membuat akta-akta otentik mengenai perbuatan hukum tertentu mengenai hak atas tanah atau hak milik atas satuan rumah susun".

Menurut Salim, Pejabat Pembuat Akta Tanah atau yang disebut dengan PPAT dalam bahasa Inggris disebut dengan land deed officials, sedangkan dalam Bahasa Belanda disebut dengan land titles registrar, mempunyai kedudukan dan peranan yang sangat penting di dalam kehidupan berbangsa dan bernegara karena pejabat ini diberi kewenangan oleh negara, untuk membuat akta pemindahan hak atas tanah dan akta-akta lainnya di negara Republik Indonesia maupun di luar negeri. ${ }^{1}$ PPAT adalah seseorang yang diangkat dan diberi kekuasaan oleh undang-undang untuk membuat akta, di mana di dalam akta yang dibuatnya itu, memuat klausula atau aturan yang mengatur hubungan hukum antara para pihak, yang berkaitan dengan hak atas tanah dan/atau hak milik atas satuan rumah susun. ${ }^{2}$

Proses pembuatan akta PPAT khususnya dalam pengalihan hak atas tanah, PPAT berkewajiban meminta validasi pajak, yaitu Pajak Penghasilan atas peralihan tanah (PPH) dan Bea Perolehan Hak atas Tanah dan Bangunan (BPHTB) untuk syarat proses pendaftaran akta PPAT tersebut ke Kantor Pertanahan setempat. Pasal 5 ayat (2) Peraturan Pemerintah Nomor 34 Tahun 2016 tentang Pajak Penghasilan Atas Penghasilan Dari Pengalihan Hak Atas Tanah Dan/Atau Bangunan, dan Perjanjian Pengikatan Jual Beli Atas Tanah Dan/Atau Bangunan Beserta Perubahannya, Selanjutnya disebut PP 34/2016 yang merupakan peraturan pelaksana dari Undang-Undang Nomor 36 Tahun 2008 tentang Perubahan Keempat atas Undang-Undang Nomor 7 Tahun 1983 tentang Pajak Penghasilan menerangkan bahwa, PPH atas penghasilan yang diperoleh dari transaksi peralihan hak atas tanah hlm. 85 .

${ }^{1}$ H. Salim, HS., Teknik Pembuatan Akta Pejabat Pembuat Akta Tanah, RajaGrafindo Persada, Jakarta, 2016, IIbid., hlm. 90. 
mewajibkan setiap transaksi yang tidak dikecualikan (pengecualian disebutkan pada Pasal 6), untuk menyetorkan PPh-nya ke Kantor Pelayanan Pajak Pratama setempat, sebelum penandatanganan akta atau bukti tertulis lainnya.

Penyetoran pajak dengan menggunakan Surat Setoran Pajak (SSP) dan bukti penyetoran, mekanismenya harus dilaporkan ke Kantor Pelayanan Pajak Pratama setempat agar dapat diteliti oleh tim validasi Kantor Pelayanan Pajak Pratama. Pasal 3 ayat (5) PP 34/2016 tentang Pajak penghasilan menjelaskan, bahwa Pejabat yang berwenang hanya menandatangani akta, keputusan, kesepakatan, atau risalah lelang atas pengalihan hak atas tanah dan/atau bangunan, apabila orang atau badan hukum tersebut telah memenuhi kewajiban sebagaimana dimaksud pada ayat (1), dan telah menyerahkan fotokopi Surat Setoran Pajak atau hasil cetakan sarana administrasi lain yang telah dilakukan penelitian oleh Kantor Pelayanan Pajak. Dari peraturan diatas jelas bahwa bukti setoran pajak harus di validasi oleh Kantor Pelayanan Pajak Pratama.

Pada Pasal 6 ayat (2), Pasal 37 ayat (1), Pasal 40 ayat (1) dan (2) Peraturan Pemerintah Nomor 24 Tahun 1997 tentang Pendaftaran Tanah (PP 24/1997), bahwa dalam pelayanan pendaftaran tanah, Kepala Kantor Pertanahan dibantu oleh PPAT untuk pembuatan akta tertentu, sebagai dasar peralihan hak atas tanah. Selambatlambatnya tujuh hari kerja, PPAT wajib menyampaikan akta-akta beserta dokumen yang diperlukan kepada Kantor Pertanahan, untuk dilakukan pelayanan pendaftaran atas tanah. Menurut penjelasan Pasal 37 ayat (2), kewajiban PPAT hanya sebatas menyampaikan akta dan dokumen pendukung ke Kantor Pertanahan.

Selain penyetoran PPh ke Kantor Pelayanan Pajak Pratama setempat, rangkaian proses berikutnya adalah penyetoran BPHTB oleh pihak pembeli ke Kantor Badan Pengelolaan Pajak dan Retribusi Daerah dalam hal ini di Kota Manado. Proses tersebut diatur dalam Pasal 85 Undang-Undang Nomor 28 Tahun 2009 tentang Pajak Daerah dan Retribusi Daerah. Pasal tersebut menjelaskan bahwa "Objek Pajak Bea Perolehan Hak atas Tanah dan Bangunan adalah Perolehan Hak atas Tanah dan/atau Bangunan", sehingga jelas pajak BPHTB yang disetorkan pada Kantor Badan Pengelola Pajak dan Retribusi Daerah ialah hasil dari peralihan hak atas tanah dan merupakan pendapatan bagi daerah.

Pajak yang dibebankan dalam proses jual beli atau pengalihan hak atas tanah dan bangunan, merupakan pendapatan negara atas sebuah transaksi pengalihan kepemilikan hak dan perolehan keuntungan atas proses pengalihan tersebut oleh warga Negara. Dalam teknis penerapannya, pembayaran pajak yang dilakukan sebelum ditandatanganinya akta jual beli adalah upaya preventif, sehingga pihak-pihak yang melakukan transaksi jual beli harus dipastikan membayar pajak bagi pendapatan negara. 
Dalam hal teknis pendaftaran akta jual beli ke kantor pertanahan setempat, akta jual beli harus dilampirkan dengan dokumen pendukung. Pada praktiknya pendaftaran akta tidak hanya dimuat dokumen pendukung tetapi harus dilampirkan bukti validasi PPH dan BPHTB sebagai bukti bahwa telah melakukan jual beli. Hal tersebut sangat berpengaruh terhadap PPAT jika akta yang dibuat PPAT tersebut telah ditanda tangani sebelum pajak divalidasi dan jika terjadi masalah akan mengakibatkan pendaftaran akta terlambat melebihi jangka waktu yang ditentukan.

\section{Rumusan Masalah}

Berdasarkan uraian latar belakang tersebut, permasalahan dalam penelitian ini adalah: Pertama, apakah akibat hukum proses validasi pajak yang tertunda terhadap pendaftaran Akta Pejabat Pembuat Akta Tanah? Kedua, bagaimana penyelesaian problematika validasi pajak peralihan hak atas tanah terhadap akta Pejabat Pembuat Akta Tanah?

\section{Tujuan Penelitian}

Adapun tujuan dari Penelitian ini yang ingin dicapai adalah: Pertama, untuk menganalisis akibat hukum dalam proses validasi pajak yang tertunda terhadap pendaftaran akta Pejabat Pembuat Akta Tanah. Kedua, untuk menganalisis penyelesaian problematika validasi pajak peralihan hak atas tanah terhadap akta Pejabat Pembuat Akta Tanah.

\section{Metode Penelitian}

Pada penelitian ini penulis menggunakan jenis penelitian Hukum Normatif. Penelitian hukum normatif yang dimaksudkan disini adalah penelitian hukum yang meletakkan hukum sebagai sistem norma. Sistem norma yang dimaksud adalah mengenai asas-asas, norma, kaidah dari peraturan perundang-undangan, putusan pengadilan, perjanjian serta doktrin (ajaran). ${ }^{3}$

Adapun bahan hukum pada penelitian ini terdiri dari: Pertama, bahan hukum primer. Bahan hukum primer yang digunakan dalam penelitian ini berupa: a. Kitab Undang-Undang Hukum Perdata; b. Peraturan Pemerintah Nomor 34 Tahun 2016 tentang Pajak Penghasilan Atas Penghasilan Dari Pengalihan Hak Atas Tanah Dan/Atau Bangunan, dan Perjanjian Pengikatan Jual Beli Atas Tanah Dan/Atau Bangunan Beserta Perubahannya; c. Kitab Undang-Undang Hukum Perdata; d.

${ }^{3}$ Mukti Fajar ND dan Yulianto Achmad, Dualisme Penelitian Hukum Normatif dan Hukum Empiris, Pustaka Pelajar, Yogyakarta, 2010, hlm. 34. 
Peraturan Pemerintah Nomor 24 Tahun 1997 tentang Pendaftaran Tanah; e. Peraturan Pemerintah Republik Indonesia Nomor 24 Tahun 2016, tentang Perubahan Atas Peraturan Pemerintah Nomor 37 Tahun 1998, tentang Peraturan Jabatan PPAT; f. Peraturan yang berkaitan dengan penelitian ini. Kedua, bahan hukum sekunder. Bahan hukum sekunder dalam penelitian ini terdiri dari buku-buku teks, jurnaljurnal hukum, pendapat para sarjana, dan hasil penelitian hukum, yang dapat memberikan penjelasan mengenai bahan-bahan hukum primer. Sementara itu bahan hukum tersier itu sendiri merupakan bahan hukum yang memberikan petunjuk, maupun penjelasan terhadap bahan hukum primer maupun bahan hukum sekunder yakni berupa kamus dan buku penunjang. Ketiga, bahan hukum tersier. Bahan hukum tersier itu sendiri merupakan bahan hukum yang memberikan petunjuk, maupun penjelasan terhadap bahan hukum primer maupun bahan hukum sekunder yakni berupa kamus dan buku penunjang.

Pendekatan Penelitian ini menggunakan Pendekatan Kasus (caseapproach) dan Pendekatan Perundang-undangan (statue approach). Pendekatan kasus (case approach) adalah suatu jenis pendekatan dalam penelitian hukum normatif yang dimana peneliti mencoba membangun argumentasi hukum dalam perspektif kasus konkrit yang terjadi di lapangan. Kasus tersebut erat kaitannya dengan kasus atau peristiwa hukum yang terjadi di lapangan. Pendekatan berikutnya yaitu Pendekatan perundang-undangan (statute approach), merupakan penelitian yang mengutamakan bahan hukum yang berupa peraturan perundang-undangan sebagai bahan acuan dasar dalam melakukan penelitian. Pendekatan perundang-undangan (statute approach) digunakan untuk meneliti peraturan perundang-undangan yang dalam penormaannya masih terdapat kekurangan atau malah menyuburkan praktik penyimpangan baik dalam tataran teknis atau dalam pelaksanaannya dilapangan. Pendekatan ini dilakukan dengan menelaah semua peraturan perundang-undangan yang bersangkut paut dengan permasalahan (isu hukum) yang sedang dihadapi. Pendekatan perundang-undangan ini misalnya dilakukan dengan mempelajari konsistensi/kesesuaian antara Undang-Undang Dasar dengan Undang-Undang, atau antara Undang-Undang yang satu dengan Undang-Undang yang lain. ${ }^{4}$

\section{Hasil Penelitian dan Pembahasan}

\section{Pengertian Pajak}

Pajak merupakan kewajiban yang dibebankan kepada masyarakat berupa iuran yang sifatnya wajib untuk dibayarkan oleh masyarakat atau wajib pajak kepada negara. Pajak yang diterima oleh negara selanjutnya akan digunakan bagi

${ }^{4}$ Soerjono Soekanto dan Sri Mamuji, Penelitian Hukum Normatif (Suatu Tinjauan Singkat), Rajawali Pers, Jakarta, 2001, hlm. 14. 
kepentingan negara, maupun pemerintah dalam pembiayaan pembangunan yang tujuannya adalah untuk kesejahteraan masyarakat itu sendiri.

Pengertian pajak berdasarkan Pasal 1 angka 1 Undang-Undang Nomor 28 Tahun 2007 tentang Ketentuan Umum dan Tata Cara Perpajakan, (selanjutnya disebut UU No. 28 Tahun 2007) adalah "kontribusi wajib kepada negara yang terutang oleh orang pribadi atau badan, yang bersifat memaksa berdasarkan undang-undang dengan tidak menerima imbalan secara langsung, dan digunakan untuk keperluan negara bagi sebesar-besarnya kemakmuran rakyat."

Macam-macam pajak dapat dibagi menurut lembaga pemungutnya menjadi 2, yakni: pajak pusat dan pajak daerah. ${ }^{5}$

1. Pajak Pusat

Pajak pusat adalah pajak yang ditetapkan oleh pemerintah pusat melalui undang-undang dan yang wewenang pemungutannya ada pada pemerintah pusat. Hasilnya dipergunakan untuk kepentingan pemerintah pusat dan pembangunan negara. Pajak pusat ini dipungut oleh pemerintah pusat yang penyelenggaraannya dilaksanakan oleh Departemen Keuangan Republik Indonesia dan hasilnya dipergunakan untuk membiayai rumah tangga negara.

Pajak pusat berkaitan dengan pajak penghasilan. Pajak penghasilan adalah pajak yang dikenakan kepada orang pribadi, atau badan atas penghasilan yang diterima atau diperoleh dalam suatu periode tahun pajak. Penghasilan itu sendiri ialah setiap tambahan kemampuan ekonomis yang berasal baik dari Indonesia maupun dari luar Indonesia, yang dapat digunakan untuk konsumsi atau untuk menambah kekayaan dengan nama dan dalam bentuk apapun. Bahwa penghasilan itu dapat berupa keuntungan usaha gaji, honorarium, hadiah, dan lain sebagainya, dengan kata lain pajak penghasilan (PPh) adalah pajak yang dikenakan kepada orang pribadi atau badan atas penghasilan yang diterima atau diperoleh dalam suatu tahun pajak. ${ }^{6}$

2. Pajak Daerah

Pajak daerah ialah pajak yang dipungut oleh Pemerintah Daerah dan digunakan untuk membiayai rumah tangga negara lebih khususnya daerah itu sendiri. Pajak daerah merupakan pajak yang ditetapkan oleh pemerintah daerah dengan Peraturan Daerah (Perda), yang wewenang pemungutannya dilaksanakan oleh pemerintah daerah dan hasilnya dipergunakan untuk membiayai pengeluaran pemerintah daerah, serta meningkatkan pembangunan di daerah. Pajak daerah terbagi menjadi pajak daerah provinsi sert pajak daerah kabupaten/kota. ${ }^{7}$

${ }^{5}$ Marihot Pahala Siahaan, Pajak Daerah dan Retribusi Daerah Berdasarkan Undang- Undang No. 28 Tahun 2009 tentang Pajak Daerah dan Retribusi Daerah, Edisi Revisi, Rajagrafindo Persada, Yogyakarta, 2010, hlm. 9.

${ }_{6}$ Adrian Sutedi, Hukum Pajak, Sinar Grafika offset, Jakarta, 2011, hlm. 51.

${ }^{7}$ Marihot Pahala Siahaan, Op. Cit., hlm. 10. 
Salah satu contoh Pajak daerah ialah berkaitan dengan pajak pembeli yaitu, bahwa peralihan hak atas tanah yang dilakukan oleh pembeli harus memenuhi syarat validasi pajak pembeli, yaitu Bea Perolehan Hak Atas Tanah dan Bangunan (BPHTB) yang dilakukan atau dibayarkan pada daerah obyek tanah tersebut berada.

\section{Pengertian dan Berbagai Cara Peralihan Hak atas Tanah}

Peralihan hak atas tanah adalah berpindahnya hak atas tanah dari pemegang hak yang lama kepada pemegang hak yang baru. Menurut Pasal 4 ayat (1) UUPA yaitu atas dasar hak menguasai dari negara sebagai yang dimaksud dalam Pasal 2 ditentukan adanya macam-macam hak atas permukaan bumi yang disebut tanah, yang dapat diberikan kepada dan dipunyai oleh orang- orang baik sendiri maupun bersama-sama dengan orang lain serta badan-badan hukum. ${ }^{8}$

Bentuk dari peralihan hak atas tanah terdapat 2 bentuk peralihan hak atas tanah tersebut ialah beralih dan dialihkan. ${ }^{9}$

1. Beralih

Beralih yang dimaksud adalah berpindahnya hak atas tanah dari pemegang hak sebelumnya kepada pihak lain karena suatu peristiwa hukum, seperti misalnya meninggalnya seseorang. Jika seseorang meninggal, maka hak atas tanah tersebut berpindah kepada ahli waris yang berhak secara yuridis sepanjang ahli waris tersebut telah memenuhi syarat sebagai subyek hak terhadap obyek hak atas tanah yang diwariskan.

2. Dialihkan

Dialihkan yang dimaksud adalah berpindahnya hak atas tanah dari pemegang hak atas tanah kepada pihak lain karena suatu perbuatan hukum, seperti misalnya jual beli, tukar menukar, wakaf, hibah, lelang, dan pemasukan dalam modal perusahaan (inbreng).

Peralihan hak atas tanah harus dengan akta PPAT, cara tersebut agar peralihan hak atas tanah menjadi otentik. Dalam Pasal 37 ayat (1) Peraturan Pemerintah Nomor 24 Tahun 1997 tentang Pendaftaran Tanah, disebutkan setiap peralihan hak atas tanah melalui jual beli hanya dapat didaftarkan jika dapat dibuktikan dengan akta yang dibuat oleh Pejabat Pembuat Akta Tanah (PPAT).

\section{Pengertian dan Mekanisme Pendaftaran Hak atas Tanah}

Pendaftaran Hak atas Tanah merupakan suatu kegiatan administrasi yang dilakukan pemilik terhadap hak atas tanah, baik dalam pemindahan hak ataupun pemberian dan pengakuan hak baru, kegiatan pendaftaran tersebut memberikan suatu kejelasan status terhadap tanah. Keadaan ini juga merupakan salah satu tujuan

\footnotetext{
8 Urip Santoso, Pendaftaran dan Peralihan Hak Atas Tanah, Kencana, Jakarta, 2010, hlm. 10.

9'Ibid., hlm. 399.
} 
UUPA untuk meletakkan dasar atas jaminan kepastian hukum mengenai hak-hak atas tanah bagi rakyat. Penyelenggaraan pendaftaran tanah tidak terlepas dari stelsel pendaftaran tanah yang dipakai dalam PP No. 24 Tahun 1997 tentang Pendaftaran Tanah yang menggunakan stelsel negatif namun mengandung unsur positif, yaitu stelsel yang dimana pelaksanaan pencatatan dalam pembukuan suatu hak di dalam daftar buku tanah atas nama subjek hak, tidak mengakibatkan bahwa subjek hak yang seharusnya berhak atas tanah itu akan kehilangan hak atas tanahnya.

Salah satu tujuan dari adanya pendaftaran tanah, sebagaimana ditetapkan dalam Pasal 3 PP No. 24 Tahun 1997 adalah untuk memberikan perlindungan hukum dan jaminan kepastian hukum kepada pemegang hak atas suatu bidang tanah, satuan rumah susun dan hak-hak lain yang terdaftar, agar dengan mudah membuktikan dirinya sebagai pemegang hak atas tanah yang bersangkutan. Untuk memberikan kepastian hukum kepada pemegang hak yang bersangkutan diberikan sertifikat hak atas tanah.

Mekanisme pendaftaran hak atas tanah, terdapat 2 sistem yaitu secara sistematik dan sporadik. Pendaftaran tanah secara sistematik menurut Pasal 1 angka 10 Peraturan Pemerintah Nomor 24 Tahun 1997 tentang Pendaftaran Tanah, adalah kegiatan pendaftaran tanah untuk pertama kali yang dilakukan secara serentak yang meliputi semua objek pendaftaran tanah yang belum didaftar dalam wilayah atau bagian wilayah suatu desa/kelurahan. Pendafrtaran tanah secara sistematik dilaksanakan melalui ajudikasi, Pasal 1 angka 8 Peraturan Pemerintah Nomor 24 Tahun 1997 tentang Pendaftaran tanah menjelaskan kegiatan yang dilaksanakan dalam rangka proses pendaftaran tanah untuk pertama kali, meliputi pengumpulan dan penetapan kebenaran data fisik dan data yuridis mengenai satu atau beberapa objek pendaftaran tanah untuk keperluan pendaftarannya.

Pendaftaran tanah secara sporadis menurut Pasal 1 angka 11 Peraturan Pemerintah Nomor 24 Tahun 1997 menjelaskan bahwa, yang dimaksud dengan pendaftaran tanah secara sporadik adalah, kegiatan pendaftaran tanah untuk pertama kali mengenai satu atau beberapa objek pendaftaran tanah dalam wilayah atau bagian wilayah suatu desa/kelurahan secara individual atau massal.

\section{Pajak yang Terkait dengan Peralihan dan Pendaftaran Hak atas Tanah}

Pajak yang terkait dengan peralihan dan pendaftaran Hak atas Tanah ialah pajak penghasilan atas peralihan tanah yang dilakukan oleh penerima maupun pemberi. Dalam pendaftaran peralihan hak atas tanah, 2 pajak tersebut menjadi 
syarat utama untuk dilakukannya proses jual beli tanah ataupun peralihan hak atas tanah yang berkaitan dengan akta-akta PPAT. Kedua pajak tersebut meliputi:

\section{Pajak Penghasilan atas Peralihan Hak atas Tanah}

Dalam Peraturan Pemerintah No. 34 Tahun 2016 tentang Pajak Penghasilan atas Penghasilan dari Pengalihan Hak atas Tanah dan/atau Bangunan, Pasal 1 ayat (2) menjelaskan pajak penghasilan berkaitan dengan penghasilan yang diterima atau diperoleh orang pribadi atau badan dari: pengalihan hak atas tanah dan/atau bangunan, atau perjanjian pengikatan jual beli atas tanah dan/atau bangunan beserta perubahannya. Penghasilan dari pengalihan hak atas tanah dan/atau bangunan sebagaimana dimaksud adalah, penghasilan yang diterima atau diperoleh pihak yang mengalihkan hak atas tanah dan/atau bangunan melalui penjualan, tukar-menukar, pelepasan hak, penyerahan hak, lelang, hibah, waris, atau cara lain yang disepakati antara para pihak. Selain penghasilan dari yang dijelaskan sebelumnya, perjanjian pengikatan jual beli atas tanah dan/ atau bangunan beserta perubahannya sebagaimana dimaksud adalah, penghasilan dari pihak penjual yang namanya tercantum dalam perjanjian pengikatan jual beli pada saat pertama kali ditandatangani perjanjian, atau pihak pembeli yang namanya tercantum dalam perjanjian pengikatan jual beli sebelum terjadinya perubahan atau adendum perjanjian pengikatan jual beli, kemudian pajak tersebut harus dibayarkan kepada Kantor Pajak Pratama setempat.

\section{Bea Perolehan Hak Atas Tanah dan Bangunan (BPHTB)}

Bea Perolehan Hak atas Tanah dan Bangunan (BPHTB) diatur dalam Undang-Undang No. 21 Tahun 1997 dan telah diubah dengan Undang-Undang No. 20 Tahun 2000 tentang Bea Perolehan Hak atas Tanah dan Bangunan, bahwa BPHTB adalah bea yang dikenakan atas perolehan hak atas tanah dan atau bangunan. Dalam setiap perolehan hak atas tanah dan bangunan, warga negara diwajibkan membayar BPHTB. Dalam bahasa sehari-hari BPHTB juga dikenal sebagai bea peralihan hak atas tanah pembeli, jika perolehan berdasarkan proses jual beli.

\section{Gambaran Umum Peralihan dan Pendaftaran Hak atas Tanah}

Pasal 37 Peraturan Pemerintah Nomor 24 Tahun 1997 tentang Pendaftaran Tanah (PP No. 24 Tahun 1997) menyebutkan bahwa peralihan hak atas tanah hanya dapat didaftarkan jika dibuktikan dengan akta yang dibuat oleh PPAT. Namun terdapat pengecualian dalam keadaan tertentu yaitu, pendaftaran dapat dilakukan tanpa menggunakan akta PPAT apabila ada berkas atau bukti lain yang kebenarannya dianggap cukup untuk mendaftar pemindahan hak oleh Kepala Kantor Pertanahan. 
Berkaitan dengan pendaftaran peralihan hak atas tanah yang dilakukan tanpa menggunakan akta PPAT, terdapat beberapa berkas ataupun bukti lain yang dapat digunakan oleh pihak Badan Pertanahan Nasional untuk dijadikan sebagai alat bukti hak yang kemudian akan diteliti kebenarannya. Bukti lain tersebut tercantum dalam Pasal 24 ayat (1) PP No. 24 Tahun 1997 yaitu, "untuk keperluan pendaftaran hak, hak atas tanah yang berasal dari konversi hak-hak lama dibuktikan dengan alat-alat bukti mengenai adanya hak tersebut berupa bukti-bukti tertulis, keterangan saksi, dan atau pernyataan yang bersangkutan yang kadar kebenarannya oleh panitia ajudikasi dalam pendaftaran tanah secara sistematik, atau oleh Kepala Kantor Pertanahan dalam pendaftaran tanah secara sporadik dianggap cukup untuk mendaftar hak, pemegang hak dan hak-hak pihak lain yang membebani-nya.

Peralihan hak atas tanah dalam hal ini jual beli dikenakan dua macam pajak yang harus dibayarkan oleh masing-masing pihak, yaitu Pajak Penghasilan (PPh) yang merupakan pajak pusat, dilaporkan pada Kantor Pelayanan Pajak Pratama (KPP Pratama) yang dibebankan kepada penjual. Kemudian Bea Perolehan Hak atas Tanah (BPHTB) yang merupakan pajak daerah dilaporkan pada Badan Pengelola Pajak dan Retribusi Daerah (BP2RD), dibebankan kepada pihak pembeli. ${ }^{10}$

PPAT hanya berwenang menandatangani akta apabila pajak yang telah dibayarkan telah dilakukan penelitian/validasi oleh Kantor Pajak, baik BPHTB yang dikenakan kepada subjek penerima peralihan hak atas tanah, maupun Pajak Penghasilan (PPh) yang dikenakan pada subjek pajak yang megalihkan hak atas tanah. Surat Setoran Pajak (SSP) dan Surat Setoran Bea Perolehan Hak atas Tanah (SSB) wajib dilakukan penelitian validasi.

Pasal 4 Peraturan Pemerintah Nomor 34 Tahun 2016 (PP No. 34 Tahun 2016) tentang Pajak Penghasilan Atas Penghasilan Dari Pengalihan Hak Atas Tanah Dan/Atau Bangunan, dan Perjanjian Pengikatan Jual Beli Atas Tanah Dan/Atau Bangunan Beserta Perubahannya, maka Setiap orang pribadi atau badan yang menerima penghasilan atas pengalihan hak atas tanah dan/atau bangunan adalah subjek PPh yang bersifat final. Pasal 2 ayat (1) huruf a PP No. 34 Tahun 2016 juga menentukan besaran Pajak Penghasilan adalah 2,5\% dari jumlah bruto nilai pengalihan hak atas tanah dan/atau bangunan. Dari penjelasan tersebut dapat dikatakan dalam proses jual beli, yang dikenakan Pajak Penghasilan adalah Penjual.

\footnotetext{
${ }^{10}$ Berdasarkan wawancara dengan PPAT Arfan Saputra, Manado, 10 Januari 2020, Pukul 13.33 WITA.
} 
Terdapat istilah umum yang digunakan pada tahapan praktik untuk pengecekan pajak yaitu validasi. PP 34 Tahun 2016 tentang Pajak Penghasilan Atas Penghasilan Dari Pengalihan Hak Atas Tanah Dan/Atau Bangunan, dan Perjanjian Pengikatan Jual Beli Atas Tanah Dan/Atau Bangunan Beserta Perubahannya tidak mengenal istilah validasi, namun menyebutkan dengan istilah penelitian tetapi juga tidak menjabarkan secara jelas pengertian penelitian tersebut.

Menurut Hendrik Kairupan selaku peneliti di kantor KPP Manado, ${ }^{11}$ penelitian adalah serangkaian kegiatan yang dilakukan untuk menilai kelengkapan pengisian surat pemberitahuan dan lampiran-lampirannya termasuk penilaian tentang kebenaran penulisan dan penghitungannya. Adapun syarat-syarat yang harus dipenuhi untuk mengajukan Penelitian/Validasi Pajak Penghasilan (PPh) dalam peralihan Hak atas Tanah dan Bangunan melalui Jual Beli, yaitu:12

1. Surat Permohonan sebagaimana tercantum dalam Lampiran I PER26/PJ/2018 tentang Perubahan Atas Peraturan Dirjen Pajak Nomor Per18/PJ.2017 tentang Tata Cara Penelitian Bukti Pemenuhan Kewajiban Penyetoran Pajak Penghasilan, Atas Penghasilan dari Kewajiban Penyetoran Pajak Penghasilan, Atas Penghasilan dari Pengalihan Hak Atas Tanah dan/atau Bangunan, dan Perjanjian Pengikatan Jual Beli Atas Tanah dan/atau Bangunan beserta Perubahannya;

2. Surat Setor Pajak yang sudah tertera Nomor Transaksi Penerimaan Negara dan Nomor Transaksi Bank/Nomor Transaksi Pos/Nomor Transaksi Potongan atau sarana administrasi lainnya yang disamakan dengan Surat Setoran Pajak;

3. Surat Pernyataan Pengalihan Hak atas Tanah dan Bangunan, atau Perjanjian Pengikatan Jual beli beserta perubahannya sebagaimana tercantum dalam Lampiran II PER-26/PJ/2018;

4. Fotokopi seluruh bukti penjualan (bukti transfer atau bukti penerimaan kas);

5. Fotokopi PBB tahun terakhir;

6. Fotokopi identitas pihak yang mengalihkan hak atas tanah (KTP beserta $\mathrm{KK})$;

7. Fotokopi NPWP Aktif pihak yang mengalihkan hak atas tanah (Penjual/Wajib Pajak PPh), dalam hal Wajib Pajak yang bersangkutan tidak memiliki NPWP dilampirkan Surat Pernyataan tidak Ber-NPWP;

8. Fotokopi identitas pihak yang menerima pengalihan hak atas tanah (KTP beserta KK);

9. Surat Kuasa apabila dikuasakan beserta KTP pihak yang menerima kuasa;

10. Surat Tugas dari Notaris kepada Staf yang menerima kuasa.

11. Dasar hukum dari BPHTB yang menjadi kewenangan Pajak Daerah adalah Undang-Undang 28 Tahun 2009 tentang Pajak Daerah dan

${ }^{11}$ Berdasarkan wawancara dengan Hendrik Kairupan, Peneliti di kantor KPP Kota Manado, Manado, 14 Januari 2020, Pukul 11.00 WITA.

${ }^{12}$ Ibid. 
Retribusi Daerah. Secara Khusus (Lex Specialist) setiap pemerintah daerah mempunyai aturan sendiri mengenai BPHTB, misalnya dalam hal ini Kota Manado yaitu Badan Pengelola Pajak dan Retribusi Daerah, melalui Peraturan Daerah Nomor 1 Tahun 2011 tentang Bea Perolehan Hak atas Tanah dan/atau Bangunan. Kedua aturan tersebut dalam ketentuan umumnya tidak menyebutkan pengertian penelitian.

Menurut Yunita Kumaat, Kepala Bidang PBB dan BPHTB di Badan Pengelola Pajak dan Retribusi Daerah Kota Manado, ${ }^{13}$ yang dimaksud dengan penelitian atau yang sering dikenal dengan validasi adalah serangkaian kegiatan untuk mencocokan data dan perhitungan pajak terutang pada Surat Pemberitahuan Pajak Daerah (SPTPD) dan/atau Surat Setoran Pajak Daerah (SSPD) sesuai dengan peraturan perundang-undangan setelah dilakukan pembayaran.

Penelitian/validasi dilakukan dengan cara menyerahkan asli dan fotokopi Surat Setoran Bea Perolehan Hak atas Tanah dan/atau Bangunan, disertai dengan dokumen pendukung yang terkait dengan peralihan hak atas tanah dan/bangunan. Adapun syarat untuk mengajukan Penelitian/Validasi BPHTB di Dinas Pendapatan Daerah, yaitu: ${ }^{14}$

1. Asli Surat Setor BPHTB;

2. Asli dan 3 lembar Fotokopi Bukti Bayar BPHTB;

3. Fotokopi Sertipikat Hak atas Tanah yang akan dialihkan;

4. Fotokopi PBB tahun berjalan;

5. Print Out Bukti Bayar PBB;

6. Fotokopi Identitas (KTP dan KK) Pihak yang menerima pengalihan hak;

7. Fotokopi Identitas (KTP dan KK) Pihak yang mengalihkan Hak atas Tanah;

8. Surat pernyataan jual beli dengan meterai yang berlaku;

9. Denah Lokasi dan Foto Lokasi;

10. Surat Kuasa apabila dikuasakan beserta KTP penerima Kuasa.

Dalam praktiknya, ditemui beberapa kendala pada proses penelitian pajak/validasi misalnya di KPP Kota Manado. Menurut Hendrik Kairupan selaku Peneliti di KPP Manado,15 yang paling sering ditemui adalah Wajib Pajak maupun Staf Notaris tidak memeriksa NPWP wajib pajak Penghasilan (PPh). Aktif ataupun Non-aktif NPWP memang tidak menghambat pembayaran Pajak Penghasilan $(\mathrm{PPh})$, namun dalam proses penelitian wajib pajak harus mempunyai

\footnotetext{
${ }^{13}$ Berdasarkan wawancara dengan Yunita Kumaat, Kepala Bidang PBB dan BPHTB di Badan Pengelola Pajak dan Retribusi Daerah Kota Manado, Manado, 15 Januari 2020, Pukul 10.30 WITA.

${ }^{14}$ Ibid.

15 Berdasarkan wawancara dengan Hendrik Kairupan, Peneliti di KPP Kota Manado, Manado, 14 Januari 2020, Pukul 11.00 WITA.
} 
NPWP aktif. Menjadi suatu hambatan kemudian apabila NPWP wajib pajak tersebut terdaftar di Kota berbeda dengan KPP tempat di mana yang bersangkutan terhutang pajak. Misalnya kasus yang terjadi di KPP Kota Manado yaitu wajib pajak A adalah seorang pensiunan. Wajib pajak A melakukan transaksi Jual-Beli atas tanah di Kota Manado tetapi Nomor Pokok Wajib Pajak (NPWP) terdaftar di Kota Jakarta Selatan. Saat dilakukan penelitian/validasi pajak jual beli baru diketahui kalau NPWP yang bersangkutan sudah tidak aktif, sedangkan proses pengajuan aktif kembali hanya dapat dilakukan di KPP dimana NPWP terdaftar, yaitu KPP Kota Jakarta Selatan.

Proses penelitian/validasi pajak di KPP Kota Manado memerlukan waktu 4 sampai 7 hari kerja. Apabila dalam prosesnya ditemui kendala administratif berupa kurang syarat maupun kesalahan seperti NPWP yang tidak aktif tersebut, maka akan diperlukan waktu yang lebih lama lagi, karena berkas yang dimasukan setelah dilengkapinya syarat yang kurang atau telah dilakukan pembenaran atas kesalahan berkas sebelumnya, akan dianggap seperti berkas yang baru, sehingga waktu proses penelitian/validasi akan seperti berkas yang baru dimasukan.

Kendala penelitian/validasi pajak juga ditemui di Badan Pengelola Pajak dan Retribusi Daerah Kota Manado. Menurut Yunita Kumaat, ${ }^{16}$ kendala yang paling banyak ditemui dalam proses penelitian/validasi jual beli di Kota Manado adalah ketidakcocokannya harga yang diajukan. Dalam peralihan hak atas tanah karena jual beli, nilai yang digunakan bukanlah NJOP seperti tertera di PBB, tetapi yang digunakan adalah NPOP. Salah satu contoh kasus di Badan Pengelola Pajak dan Retribusi Daerah Kota Manado, NJOP pada PBB adalah Rp. 500.000.000,00 sedangkan harga yang diajukan adalah Rp. 550.000.000,00, setelah dilakukan penelitian ternyata penjual telah membuka iklan online dengan harga Rp.1.000.000.000,00, terlebih lagi karena letak tanah yang menjadi objek pajak berada di pinggir jalan raya kota, sehingga nilai Rp.550.000.000,00 dinilai tidak wajar.

Jangka waktu proses penelitian/validasi BPHTB di Badan Pengelola Pajak dan Retribusi Daerah Kota Manado sama dengan KPP Kota Manado, yaitu 4 sampai 7 hari kerja dan tidak ada perbedaan waktu antara proses pengajuan penelitian/validasi saat pertama kali maupun penelitian/validasi BPHTB karena kekurangan syarat maupun perbaikan. Menurut PPAT Arfan Saputra, ${ }^{17}$ proses penelitian pajak baik di KPP Kota Manado maupun di Badan Pengelola Pajak dan Retribusi Daerah Kota Manado tidak dapat diprediksi secara tepat berapa lama akan selesai, meskipun telah diberikan jangka waktu oleh peraturan yaitu 7 hari. Apabila

\footnotetext{
16 Berdasarkan wawancara dengan Yunita Kumaat, Kepala Bidang PBB dan BPHTB di Badan Pengelola Pajak dan Retribusi Daerah Kota Manado, Manado, 15 Januari 2020, Pukul 10.00 WITA.

${ }^{17}$ Berdasarkan wawancara dengan PPAT Arfan Saputra, Manado, 10 Januari 2020, Pukul 13.45 WITA.
} 
terdapat kesalahan mapun kekurangan syarat, maka pengajuan penelitian/validasi tersebut harus menunggu hingga waktu 7 hari lagi. Untuk itu, PPAT harus menunggu proses penelitian/validasi tersebut selesai, setelah itu baru dapat dilakukan tanda tangan akta.

\section{Penutup}

Sebagai penutup peneliti menyajikan kesimpulan berdasarkan pembahasan dariuraian di atas menyimpulan sebagai berikut: Pertama, akibat hukum proses validasi pajak yang tertunda terhadap Pendaftaran Akta PPAT adalah, bahwa validasi pajak merupakan tugas administrasi negara, tidak adanya validasi terhadap pajak jual beli mengakibatkan tidak dapat dilakukannya pendaftaran jual beli untuk peralihan hak atas tanah ke Kantor Pertanahan. Secara hukum adat, jual beli yang dibayar secara lunas mengakibatkan pembeli telah memperoleh hak atas tanah tersebut, namun karena belum dilakukan pendaftaran akta jual beli ke Kantor Pertanahan, maka tanah tersebut secara yuridis belum beralih ke Pembeli. Pentingnya dilakukan pendaftaran terhadap akta jual beli di Kantor Pertanahan untuk balik nama sertifikat dari penjual ke pembeli adalah, sertifikat merupakan tanda kepemilikan atas tanah yang sah. Kedua, penyelesaian Problematika Validasi Pajak Peralihan Hak atas Tanah Terhadap Akta Pejabat Pembuat Akta Tanah apabila mengacu pada problematika yang ditemui dalam praktik, proses penelitian/validasi pajak BPHTB di Badan Pengelola Pajak dan Retribusi Daerah sama dengan validasi pajak Penghasilan di Kantor Pajak Pratama, yaitu terdapat kekurangan berkas yang diajukan atau kurang bayar terhadap pajak yang telah dibayarkan sebelumnya, wajib pajak secara pribadi maupun melalui kuasanya diminta untuk melakukan perbaikan atau melengkapi berkas yang kurang, untuk dapat dijukan penelitian/validasi kembali, hal ini membutuhkan waktu yang lama, penyelesaian yang dilakukan wajib pajak harus mengikuti perintah kantor pajak misalnya, dalam NPWP yang tidak aktif harus mengaktifkan dahulu selain penyelesaian pajak, dan PPAT di Kota Manado harus membuat pernyataan keterlambatan atas Akta Jual Beli tersebut.

Berdasarkan kesimpulan dari hasil penelitian ini, peneliti menyajikan saran yang diharapkan kemudian dapat memberikan manfaat maupun masukan bagi semua pihak, agar dapat meminimalisir problematika dalam proses validasi terkait pajak jual beli atas objek tanah. Adapun saran yang dimaksud adalah sebagai berikut: Pertama, PPAT harus memperhatikan administrasi di Kantor Pajak setempat agar syarat-syarat yang diajukan dapat berjalan dengan baik; Kedua, kantor pajak maupun PPAT agar memberikan pengertian mengenai pajak, 
dan membuatkan surat pernyataan jika ada kurang bayar atau dokumen yang tidak dapat diterima oleh Kantor Pajak. Ketiga, untuk masyarakat yang akan melakukan jual beli tanah sebaiknya aktif untuk mencari informasi syarat dan risiko dalam melakukan jual beli tanah.

\section{Daftar Pustaka}

\section{Buku}

HS., H. Salim, Teknik Pembuatan Akta Pejabat Pembuat Akta Tanah, Raja Grafindo Persada, Jakarta, 2016.

ND, Mukti Fajar dan Achmad, Yulianto, Dualisme Penelitian Hukum Normatif dan Hukum Empiris, Pustaka Pelajar, Yogyakarta, 2010.

Santoso, Urip, Hukum Agraria dan Hak-Hak Atas Tanah, Cetakan Kedua, Prenada Media, Jakarta, 2005.

Siahaan, Marihot Pahala, Pajak Daerah dan Retribusi Daerah Berdasarkan UndangUndang No. 28 Tahun 2009 tentang Pajak Daerah dan Retribusi Daerah, Edisi Revisi, Rajagrafindo Persada, Yogyakarta, 2010.

Soekanto, Soerjono dan Mamuji, Sri, Penelitian Hukum Normatif (Suatu Tinjauan Singkat), Rajawali Pers, Jakarta, 2001.

Soeroso, Pengantar Ilmu Hukum, Sinar Grafika, Jakarta, 2006.

Sutedi, Adrian, Hukum Pajak, Sinar Grafika offset, Jakarta, 2011.

\section{Peraturan Perundang-undangan}

Kitab Undang-Undang Hukum Perdata (KUHPerdata).

Undang-Undang Nomor 5 Tahun 1960 tentang Peraturan Dasar Pokok-Pokok Agraria, Lembaran Negara Republik Indonesia Tahun 1960, Tambahan Lembaran Negara RI Nomor 2043.

Peraturan Pemerintah Nomor 24 Tahun 1997 tentang Pendaftaran Hak atas Tanah, Lembaran Negara Republik Indonesia Tahun 1997, Tambahan Lembaran Negara RI Nomor 3696.

Peraturan Pemerintah Nomor 37 Tahun 1998 tentang Peraturan Pejabat Pembuat Akta Tanah, Lembaran Negara Republik Indonesia Tahun 1998, Tambahan Lembaran Negara RI Nomor 3746. 